\title{
Formation of 8-nitroguanine, a nitrative DNA lesion, in inflammation-related carcinogenesis and its significance
}

\author{
Yusuke Hiraku
}

Received: 26 September 2009/ Accepted: 15 October 2009/Published online: 19 November 2009

(C) The Japanese Society for Hygiene 2009

\begin{abstract}
Chronic infection and inflammation contribute to a substantial part of environmental carcinogenesis. Recently, it has been estimated that chronic inflammation accounts for approximately $25 \%$ of cancer cases. Various infectious diseases and physical, chemical, and immunological factors participate in inflammation-related carcinogenesis. Under inflammatory conditions, reactive oxygen and nitrogen species, which are generated from inflammatory and epithelial cells, may play an important role in carcinogenesis by causing DNA damage. 8-Nitroguanine is a mutagenic DNA lesion formed during chronic inflammation. In an earlier publication, our group reported the results of an immunohistochemical analysis of animals infected with the liver fluke Opisthorchis viverrini and demonstrated for the first time that 8-nitroguanine was formed at the sites of carcinogenesis. This DNA lesion was found to accumulate in the carcinogenic process in clinical specimens of cancer-prone inflammatory diseases caused by various pathogens, including human papillomavirus and Epstein-Barr virus. Moreover, strong 8-nitroguanine formation in tumor tissues was closely associated with a poor prognosis. On the basis of these findings, 8-nitroguanine could be a potential biomarker to evaluate the risk of inflammation-related carcinogenesis and the prognosis of cancer patients. In this review, the significance of 8-nitroguanine formation in inflammation-related carcinogenesis and tumor progression will be discussed.
\end{abstract}

\section{Y. Hiraku $(\bowtie)$}

Department of Environmental and Molecular Medicine,

Mie University Graduate School of Medicine,

Mie 514-8507, Japan

e-mail: y-hiraku@doc.medic.mie-u.ac.jp
Keywords Carcinogenesis - DNA damage . Inflammation $\cdot 8$-Nitroguanine $\cdot$ Reactive nitrogen species

\section{Introduction}

In 1863, Rudolf Virchow noted leucocytes in neoplastic tissues and made a connection between inflammation and cancer. Since then, there has been growing research interest in the possibility of a link between chronic inflammation and carcinogenesis, and the observation that many malignancies actually do arise from areas of infection and inflammation provides support to this hypothesis $[1,2]$. Recently, chronic inflammation has been estimated to account for approximately $25 \%$ of all cancer cases worldwide [3]. Epidemiological and experimental studies have provided evidence indicating that various infectious agents constitute one of the main causes of cancer $[2,4]$. The International Agency for Research on Cancer (IARC) has estimated that approximately $18 \%$ of cancer cases worldwide is attributable to infectious diseases caused by bacteria, viruses, and parasites [4] (Table 1). In addition to infection, many other physical, chemical, and immunological factors participate in carcinogenesis mediated by chronic inflammation $[2,5]$ (Table 2).

During chronic inflammation, reactive oxygen species (ROS) and reactive nitrogen species (RNS) capable of causing damage to various cellular constituents, such as nucleic acids, proteins, and lipids, are generated from inflammatory and epithelial cells. These reactive species may play an important role in carcinogenesis by causing oxidative and nitrative DNA damage [6-8]. ROS induce the formation of potentially mutagenic oxidative DNA lesions, such as 8-oxo-7,8-dihydro-2'-deoxyguanosine (8-oxodG) [9-12]. Misincorporation of adenine occurs 
Table 1 Cancer caused by infectious agents (adapted and modified from the IARC [4])

\begin{tabular}{|c|c|c|c|c|}
\hline Infectious agents & $\begin{array}{l}\text { IARC } \\
\text { classification }^{\mathrm{a}}\end{array}$ & Cancer site & $\begin{array}{l}\text { Number of } \\
\text { cancer cases }\end{array}$ & $\begin{array}{l}\text { Percentage of } \\
\text { cancer cases worldwide }\end{array}$ \\
\hline \multicolumn{5}{|l|}{ Bacterium } \\
\hline Helicobacter pylori & 1 & Stomach & 490,000 & 5.4 \\
\hline \multicolumn{5}{|l|}{ Viruses } \\
\hline \multicolumn{5}{|l|}{$\mathrm{HPV}^{\mathrm{b}}$} \\
\hline High-risk types & 1 & Cervix and other sites & 550,000 & 6.1 \\
\hline Low-risk types & $2 \mathrm{~B}$ & & & \\
\hline $\mathrm{HBV}$ and $\mathrm{HCV}$ & 1 & Liver & 390,000 & 4.3 \\
\hline EBV & 1 & Lymphoma & 99,000 & 1.1 \\
\hline & & Nasopharyngeal carcinoma & & \\
\hline HHV-8 & $2 \mathrm{~A}$ & Kaposi sarcoma & 54,000 & 0.6 \\
\hline HTLV-1 & 1 & Leukemia & 9,000 & 0.1 \\
\hline \multicolumn{5}{|l|}{ Parasites } \\
\hline Schistosoma haematobium & 1 & Bladder & 2,700 & 0.1 \\
\hline Liver flukes & & & & \\
\hline Opisthorchis viverrini & 1 & Intra- and extrahepatic bile ducts & 800 & \\
\hline Clonorchis sinensis & $2 \mathrm{~A}$ & & & \\
\hline Total infection-related cancers & & & $1,600,000$ & 17.7 \\
\hline Total cancers $(1995)$ & & & $9,000,000$ & 100 \\
\hline
\end{tabular}

IARC International Agency for Research on Cancer

${ }^{a}$ IARC classification: Group 1, carcinogenic to humans; Group 2A, probably carcinogenic to humans; Group 2B, possibly carcinogenic to humans

${ }^{\mathrm{b}} H P V$ Human papillomavirus, $H B V$ hepatitis B virus, $H C V$ hepatitis $\mathrm{C}$ virus, $H H V-8$ human herpesvirus-8, $H T L V-1$ human T-lymphotropic virus type 1

Table 2 Chronic inflammatory diseases prone to carcinogenesis (adapted and modified from Coussens and Werb [2])

\begin{tabular}{|c|c|c|}
\hline Pathologic conditions & Associated neoplasms & Etiologic agents \\
\hline Asbestosis, silicosis & Mesothelioma, lung carcinoma & $\begin{array}{l}\text { Asbestos fibers } \\
\text { Silica particles }\end{array}$ \\
\hline Bronchitis & Lung carcinoma & $\begin{array}{l}\text { Silica, asbestos, smoking } \\
\quad \text { (nitrosamines, peroxides) }\end{array}$ \\
\hline Cystitis, bladder inflammation & Bladder carcinoma & $\begin{array}{l}\text { Chronic indwelling } \\
\text { Urinary catheters }\end{array}$ \\
\hline Gingivitis, lichen planus & Oral squamous cell carcinoma & \\
\hline $\begin{array}{l}\text { Inflammatory bowel disease } \\
\text { Crohn's disease } \\
\text { Chronic ulcerative colitis }\end{array}$ & Colorectal carcinoma & \\
\hline Lichen sclerosus & Vulvar squamous cell carcinoma & \\
\hline $\begin{array}{l}\text { Chronic pancreatitis } \\
\text { Hereditary pancreatitis }\end{array}$ & Pancreatic carcinoma & $\begin{array}{l}\text { Alcoholism, mutation in } \\
\text { trypsinogen gene on } \\
\text { chromosome } 7\end{array}$ \\
\hline Reflux esophagitis & Esophageal carcinoma & Gastric acids \\
\hline Barrett's esophagus & & \\
\hline Sialadenitis & Salivary gland carcinoma & \\
\hline Sjogren syndrome & MALT lymphoma & \\
\hline Hashimoto's thyroiditis & & \\
\hline Skin inflammation & Melanoma & Ultraviolet light \\
\hline
\end{tabular}


opposite 8-oxodG during DNA synthesis and thus leads to $\mathrm{G} \rightarrow \mathrm{T}$ transversions [13, 14]. These ROS are generated from not only inflammatory cells but also other multiple sources, including carcinogenic chemicals and electron transport chain in mitochondria [7]. RNS, however, including nitric oxide (NO), are generated particularly under inflammatory conditions via the expression of inducible nitric oxide synthase (iNOS) in inflammatory and epithelial cells. $\mathrm{NO}$ reacts with superoxide $\left(\mathrm{O}_{2}^{-}\right)$to form highly reactive peroxynitrite $\left(\mathrm{ONOO}^{-}\right)$, which interacts with guanine to produce nitrative and oxidative DNA lesions, such as 8-nitroguanine and 8-oxodG, respectively $[15,16]$. 8-Nitroguanine formed in DNA is chemically unstable and can be spontaneously released, resulting in the formation of an apurinic site [15] (Fig. 1). The apurinic site forms a pair preferably with adenine during DNA synthesis, leading to $\mathrm{G} \rightarrow \mathrm{T}$ transversions [17]. DNA polymerase $\zeta$ is involved in cellular tolerance to NO-induced DNA damage through translesion DNA synthesis past the apurinic site, but this error-prone polymerase may contribute to extensive point mutations [18]. Alternatively, adenine is preferentially incorporated opposite 8-nitroguanine during DNA synthesis [19], resulting in $G \rightarrow T$ transversions. Therefore, 8-nitroguanine is a mutagenic DNA lesion involved in inflammation-related carcinogenesis.

In an in vivo experimental animal system, it has been shown that 8-nitroguanine is formed via inflammation in the lung of mice with viral pneumonia [20]. Our group has focused on the role of 8-nitroguanine in infection- and inflammation-related carcinogenesis and examined the formation of this DNA lesion in experimental animals and clinical specimens by immunohistochemical analysis using a specific anti-8-nitroguanine antibody produced in our laboratory [21, 22]. Studying hamsters infected with the liver fluke Opisthorchis viverrini (OV), we were the first to demonstrate that 8-nitroguanine is formed at the site of carcinogenesis [21, 23, 24]. We also examined 8-nitroguanine formation in biopsy and surgical specimens of patients with cancer-prone infectious diseases induced by bacteria (Helicobacter pylori) [25], viruses (hepatitis C virus [26], human papillomavirus (HPV) [27], EpsteinBarr virus (EBV) [28]), parasites (OV) [29], and inflammatory diseases (oral lichen planus and leukoplakia) [30, 31]. Moreover, we investigated the prognostic significance of 8-nitroguanine in patients with soft tissue sarcoma [32, 33]. This article reviews our recent studies on 8-nitroguanine formation during inflammation-related carcinogenesis and discusses the significance of its formation.

\section{Parasitic infection: liver fluke and cholangiocarcinoma}

Infection with the liver fluke $\mathrm{OV}$ is a major risk factor of cholangiocarcinoma, especially in the northeastern region of Thailand [34, 35]. A major cause of OV infection and cholangiocarcinoma in this region is the consumption of raw fish contaminated with this parasite [36] (Fig. 2a). Approximately $70 \%$ of $\mathrm{OV}$-induced cholangiocarcinoma occurs in the intrahepatic bile ducts [37], whereas the incidence of intrahepatic cholangiocarcinoma independent of $\mathrm{OV}$ infection is generally low. As a model of inflammation-related carcinogenesis, we investigated 8-nitroguanine formation in the liver of $\mathrm{OV}$-infected hamsters by fluorescent immunohistochemistry. We found that 8-nitroguanine was formed in the bile duct epithelial cells [23], and these observations were the first from an in vivo study to show that this DNA lesion is formed at the sites of inflammation-related carcinogenesis. In the acute phase (21-30 days post-infection), the immunoreactivity of 8nitroguanine was prominently observed in inflammatory cells, whereas in the chronic phase (90-180 days postinfection), this DNA lesion was formed in bile duct epithelial cells [21]. Repeated OV infections increased 8-nitroguanine formation and iNOS expression in the
Fig. 1 8-Nitroguanine formation under chronic inflammation. iNOS inducible nitric oxide synthase, $N O$ nitric oxide, $U V$ ultraviolet light, $\mathrm{O}_{2}^{-}$superoxide, $\mathrm{ONOO}^{-}$ peroxynitrite

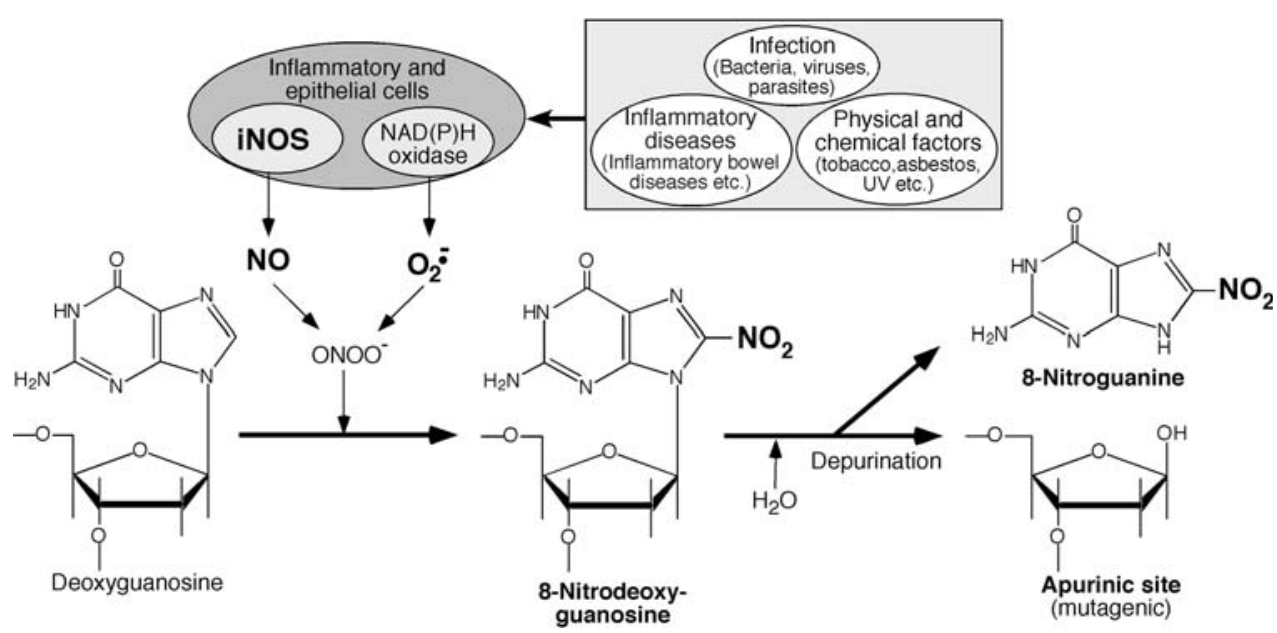




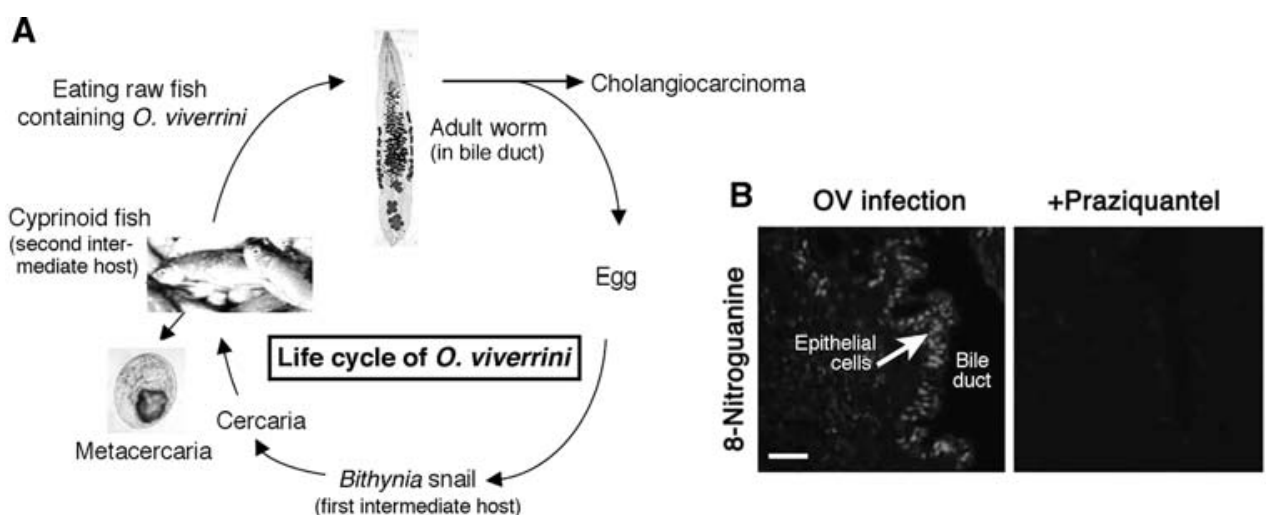

Fig. 2 Opisthorchis viverrini $(\mathrm{OV})$-induced cholangiocarcinoma and 8-nitroguanine formation. a Life cycle of OV. Eggs laid from adult worms in bile ducts are passed through the bile into the duodenum and excreted with feces. Eggs hatch in the digestive tracts of Bithynia snails (first intermediate host). Free-living cercariae transform to metacercariae encysted mainly in the muscle of fish (second intermediate host). Metacercariae are infective to humans, when they ingest raw or inadequately cooked fish. Metacercariae are digested and excysted juvenile flukes migrate up through the bile duct.

epithelium of bile ducts compared with a single infection [24]. Moreover, the treatment of OV-infected hamsters with the antiparasitic drug praziquantel was found to reduce 8-nitroguanine formation [38] (Fig. 2b). We also examined 8-nitroguanine formation in surgical specimens of cholangiocarcinoma patients. Immunohistochemical analysis revealed that 8-nitroguanine formation occurred to a much greater extent in cancerous tissues than in noncancerous tissues [29]. These findings raised the possibility that 8-nitroguanine can be used as a biomarker to evaluate the risk of inflammation-related carcinogenesis and the efficacy of drug treatment.

The local specific inflammatory response may participate in parasite-induced carcinogenesis. In OV-infected hamsters, an antigen of this parasite was distributed in the intrahepatic bile duct epithelial cells, and the presence of the antigen was associated with inflammatory cell infiltration [39]. Our study using the RAW 264.7 macrophage cell line and OV-infected hamsters revealed that the OV antigen induced an inflammatory response through the Tolllike receptor (TLR)-2-mediated pathway, leading to the expression of iNOS and cyclooxygenase-2 (COX-2) via activation of nuclear factor- $\kappa \mathrm{B}(\mathrm{NF}-\kappa \mathrm{B})[38,40]$. COX-2 mediates cancer development via various pathogenic events, including inflammatory responses, inhibition of apoptosis, and angiogenesis [41-43]. NF- $\kappa \mathrm{B}$ is a key player in inflammation and regulates the expression of various genes involved in controlling the inflammatory response, including iNOS $[43,44]$. NF- $\kappa \mathrm{B}$ also participates in the promotion and progression of inflammation-related cancer $[45,46]$. TLRs activate signal transduction pathways leading to the nuclear translocation of NF- $\kappa \mathrm{B} /$ Rel-type b 8-Nitroguanine formation in bile duct epithelium of an OV-infected hamster. Male Syrian hamsters were infected with OV for 30 days, and praziquantel was given orally 7 days before sacrifice. Paraffin sections of liver tissues were incubated first with rabbit polyclonal anti-8-nitroguanine antibody and then with Alexa 594-labeled goat anti-rabbit immunoglobulin $\mathrm{G}$ (IgG). The immunoreactivity of 8-nitroguanine was seen in the nucleus of bile duct epithelial cells, and its formation diminished after praziquantel treatment [38]. Scale bar $25 \mu \mathrm{m}$

transcription factors $[47,48]$ and subsequently participate in inflammation-related carcinogenesis [49]. It has been reported recently that extracellular proteoglycans upregulated in carcinoma tissues activate myeloid cells through TLR2 to stimulate metastasis [50]. Therefore, TLR-mediated inflammatory responses may participate in carcinogenesis and tumor progression, and the molecules involved in this process could be potential therapeutic targets for inflammation-related cancer.

\section{Viral infection}

Human papillomavirus and cervical cancer

Cervical cancer is the second most common cancer among women worldwide and is most common among women in many regions of developing countries [51]. Virtually all cases of cervical cancer are attributable to persistent infection with HPV [52-54]. In 2008, Harald zur Hausen was awarded with the Nobel Prize for the discovery of HPV. Although IARC previously determined that HPV-16 and -18 are carcinogenic to humans (group 1) [55], other high-risk types of HPV (HPV-31, -33, -35, -39, -45, -51, $-52,-56,-58,-59$, and -66 ) have recently been assessed as group 1 carcinogens [56]. However, these HPV types can differ by an order of magnitude in terms of being risk factors for cervical cancer [56]. There are also low-risk HPV types (HPV-6 and -11); these are capable of causing condyloma acuminatum and have been evaluated to be possibly carcinogenic to humans (Group 2B) [56]. HPV infection is a necessary event preceding the development of 
premalignant lesions in the cervical epithelium, referred to as cervical intraepithelial neoplasia (CIN), which partially progresses to cancer [57]. HPV oncoproteins E6 and E7 are known to participate in HPV-induced cervical carcinogenesis by inactivating the tumor suppressor gene products, p53 and $\mathrm{Rb}$, respectively [54, 58]. However, it has been suggested that these oncoproteins are not sufficient on their own and that additional cellular events are required for cervical carcinogenesis [59]. Ha-ras activation in HPV16immortalized human cervical cells resulted in malignancy, while transfection of HPV16 DNA alone into cervical cells did not [60]. Human protooncogenes, including the c-Haras gene, can be activated via oxygen radical-induced DNA damage [61]. Therefore, oxidative and nitrative DNA damage may be involved in cervical carcinogenesis.

The results of recent studies suggest that inflammation plays a substantial role in HPV-mediated cervical carcinogenesis. Although it is still unclear whether HPV infection alone induces the inflammatory states, epidemiological studies have revealed that cervical inflammation in women with HPV infection is associated with cervical neoplasia [57, 62]. There are reports of co-infection with HPV and other pathogens increasing the risk of cervical cancer. Among HPV DNA-positive women, seropositivity of herpes simplex virus- 2 has been associated with an increased risk of invasive cervical carcinoma [63]. Molecular epidemiological studies have revealed that COX-2 is overexpressed in cervical cancer [64, 65]. Therefore, chronic inflammation may play an important role in cervical carcinogenesis.
We examined 8-nitroguanine formation in cervical biopsy specimens of patients with CIN and condyloma acuminatum. 8-Nitroguanine was formed in atypical epithelial cells of CIN patients but not in condyloma acuminatum patients (Fig. 3a). Statistical analysis revealed that 8-nitroguanine immunoreactivity was significantly increased with increasing CIN grade [27]. Several studies have demonstrated that p16 is expressed in patients with CIN and cervical cancer, leading to the proposal that p16 may be a biomarker of cervical neoplasia [66-68]. The HPV E7 protein binds to $\mathrm{Rb}$ protein, leading to the release of the transcription factor E2F [58], which induces the expression of p16-related transcripts [69]. In our study, p16 was expressed in cervical epithelial cells of both CIN and condyloma acuminatum patients, whereas 8-nitroguanine formation was observed only in CIN patients [27] (Fig. 3b). These results suggest that high-risk HPV types mediate 8-nitroguanine formation, leading to dysplastic changes in cervical tissues and carcinogenesis, whereas p16 expression is simply a marker of HPV infection regardless of virus type. Thus, 8-nitroguanine is a more suitable and promising biomarker than p16 for evaluating the risk of cervical carcinogenesis. Inflammation-mediated DNA damage, which precedes the genomic abnormalities caused by HPV oncoproteins, may play an important role in carcinogenesis.

\section{Epstein-Barr virus and nasopharyngeal carcinoma}

Nasopharyngeal carcinoma (NPC) and Burkitt lymphoma are strongly associated with EBV infection [70], and both
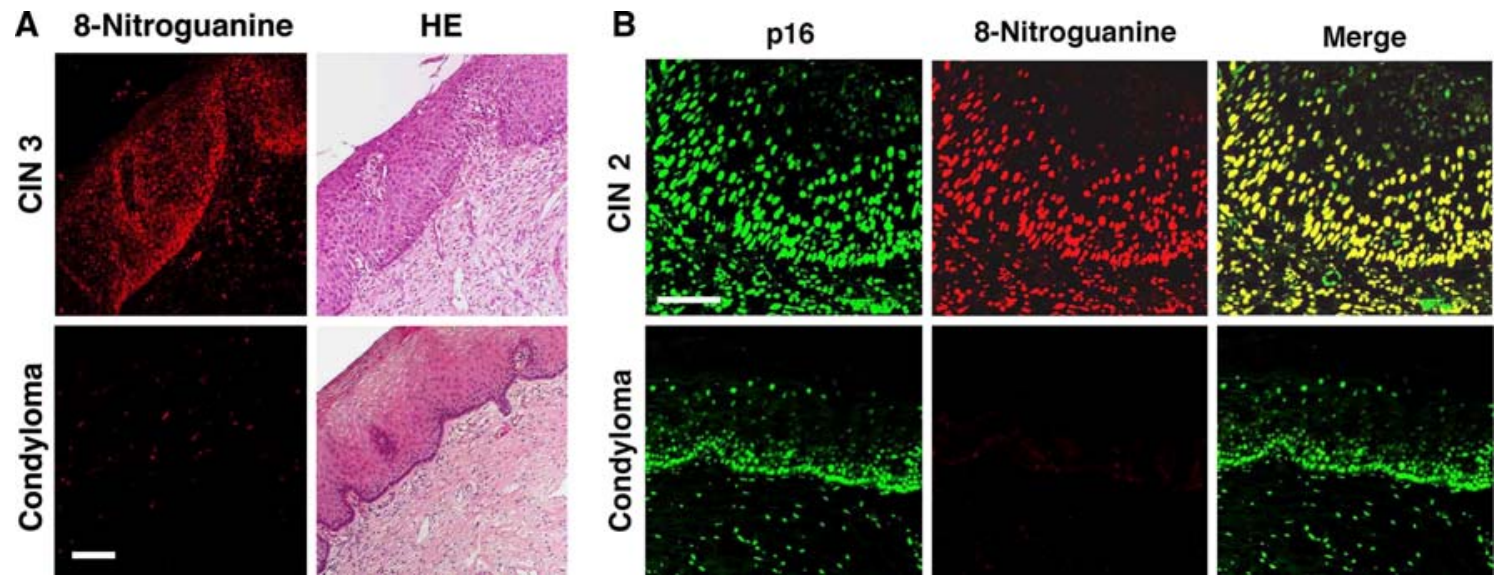

Fig. 3 8-Nitroguanine formation and p16 expression in biopsy specimens of patients with cervical dysplasia. a Immunoreactivity of 8-nitroguanine in a biopsy specimen of a patient with cervical intraepithelial neoplasia $(C I N)$ grade 3. 8-Nitroguanine was formed in the nuclei of atypical epithelial cells of the CIN patient, whereas little or no DNA damage was observed in condyloma acuminatum patients. 8-Nitroguanine formation was examined as described in the caption to Fig. 2. b Comparison of 8-nitroguanine and p16 staining in patients with CIN grade 2 and condyloma acuminatum. Paraffin sections were first incubated with the primary antibodies (rabbit polyclonal anti8-nitroguanine and mouse monoclonal anti-p16 antibodies) and then with the secondary antibodies (Alexa 594-labeled goat anti-rabbit IgG and Alexa 488-labeled goat anti-mouse IgG antibodies). 8-Nitroguanine (red) was colocalized with p16 (green) in the nuclei of atypical epithelial cells (yellow) in CIN, whereas, little or no 8-nitroguanine formation occurred in condyloma acuminatum [27]. Scale bar $50 \mu \mathrm{m}$ 
account for approximately $1 \%$ of cancer cases worldwide [4]. NPC is an epithelial tumor with a high prevalence in southern China where the incidence rate is about $25-50$ per 100,000 people-year; this is 100 -fold higher than that in the Western world [71, 72]. Latent EBV infection is detected in cancer cells of virtually all cases of undifferentiated NPC in endemic regions [4, 73].

We examined 8-nitroguanine formation in biopsy specimens of nasopharyngeal tissues from patients with nasopharyngitis and NPC in southern China. 8-Nitroguanine was formed in epithelial cells of EBV-positive patients with chronic nasopharyngitis, and its intensity was significantly stronger in cancer cells of NPC patients [28]. Intensive immunoreactivity of iNOS was detected in the cytoplasm of 8-nitroguanine-positive cancer cells. We also examined the mechanism for EBV-induced 8-nitroguanine formation in nasopharyngeal epithelial cells. EBV-encoded RNAs (EBERs) and a viral protein latent membrane protein 1 (LMP1) were detected in cancer cells from all EBVinfected patients. LMP1 induces the expression and nuclear accumulation of epidermal growth factor receptor (EGFR) $[74,75]$, which in turn interacts with the signal transducer and activator of transcription-3 (STAT3) in the nucleus, leading to transcriptional activation of iNOS [76]. In our study, EGFR and phosphorylated STAT3 were strongly expressed in cancer cells of NPC patients. Interleukin (IL)-6, which mediates STAT3 expression, was expressed in macrophages of nasopharyngeal tissues of EBV-infected patients. In LMP1-expressing cultured cells, EGFR was accumulated in the nucleus, and the addition of IL-6 induced the expression of phosphorylated STAT3 and iNOS and the formation of 8-nitroguanine [28]. These results suggest that EBV infection induces nuclear accumulation of EGFR and IL-6-mediated STAT3 activation, leading to iNOS expression and 8-nitroguanine formation. The proposed mechanism of EBV-induced carcinogenesis is shown in Fig. 4.

In addition to EBV infection, environmental and dietary factors have been proposed as contributory factors to NPC carcinogenesis. The traditional foods of southern China, such as salted fish and other preserved food containing volatile nitrosoamines, are important carcinogenic factors of NPC [77]. Moreover, Chinese-style salted fish contains substances capable of activating latently infected EBV [70]. IARC has evaluated Chinese-style salted fish to be a Group 1 carcinogen [78]. An epidemiological study revealed that the use of herbal medicine increases the risk of NPC, probably through EBV reactivation or a direct promoting effect on EBV-transformed cells [79]. A phorbol diester, an EBV-activating substance, has been identified in the soil collected from under Chinese tallow Sapium sebiferum [80]. However, the contribution of these environmental factors to EBV-mediated carcinogenesis is not

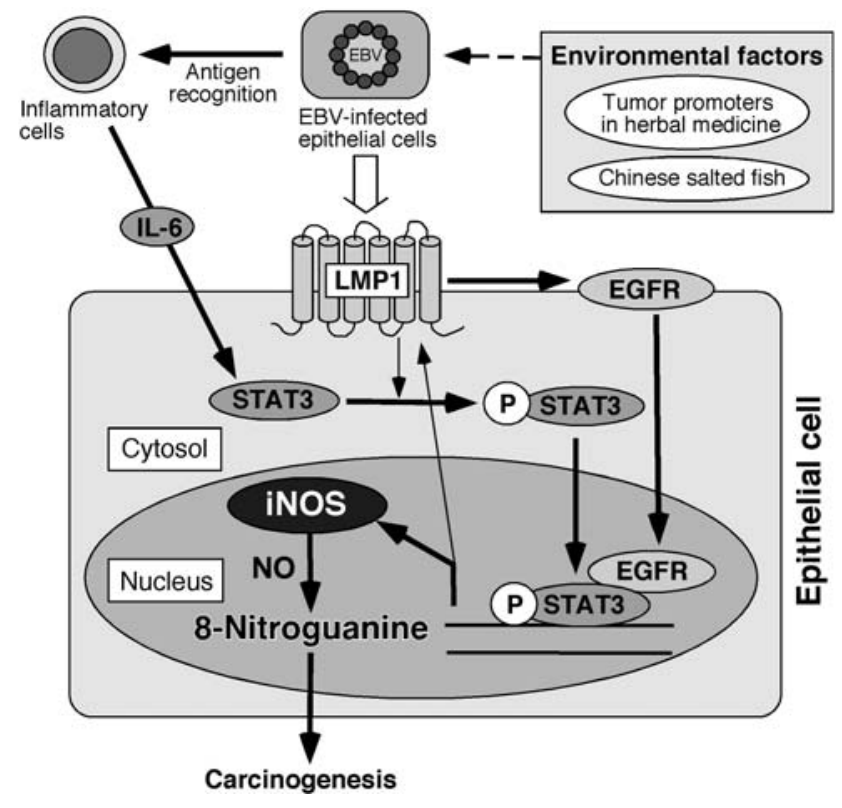

Fig. 4 Proposed mechanism of 8-nitroguanine formation and carcinogenesis mediated by Epstein-Barr virus $(E B V)$ infection. $E G F R$ epidermal growth factor receptor, $L M P 1$ latent membrane protein 1 , (p)STAT3 (phosphorylated) signal transducer and activator of transcription-3, IL interleukin

yet fully understood, and thus future epidemiological and experimental studies are needed.

\section{8-Nitroguanine and prognosis of cancer patients}

We have examined whether 8-nitroguanine participates not only in the onset of carcinogenesis but also in tumor progression and the poor prognosis of cancer patients. Malignant fibrous histiocytoma (MFH) is soft tissue sarcoma occurring in adults [81], and it has been proposed that it is accompanied with inflammatory responses. The expression of cytokines in inflammatory MFH may account for local inflammatory cell infiltration and the aggressive nature of the malignant cells [82]. Lymphocytes, monocytes, and macrophages were observed to be infiltrated in the early phase of experimentally induced rat sarcoma [83]. These findings give rise to the hypothesis that these inflammatory responses may play a role in the pathogenesis of MFH.

We investigated the distribution of 8-nitroguanine and the expression of inflammation-related molecules in surgical specimens of MFH patients by immunohistochemical analysis. 8-Nitroguanine immunoreactivity was clearly observed in the tumor cells, whereas little or no 8-nitroguanine formation occurred in adjacent non-tumor tissues. The Kaplan-Meier method revealed that strong 8-nitroguanine staining is associated with a poor prognosis of 
Fig. 5 Proposed mechanism of inflammation-related carcinogenesis and tumor development through 8nitroguanine formation. $N F-\kappa B$ nuclear factor- $\kappa \mathrm{B}$, $H I F$ hypoxia-inducible factor, 8-oxodG 8-oxo-7,8-dihydro-2'deoxyguanosine

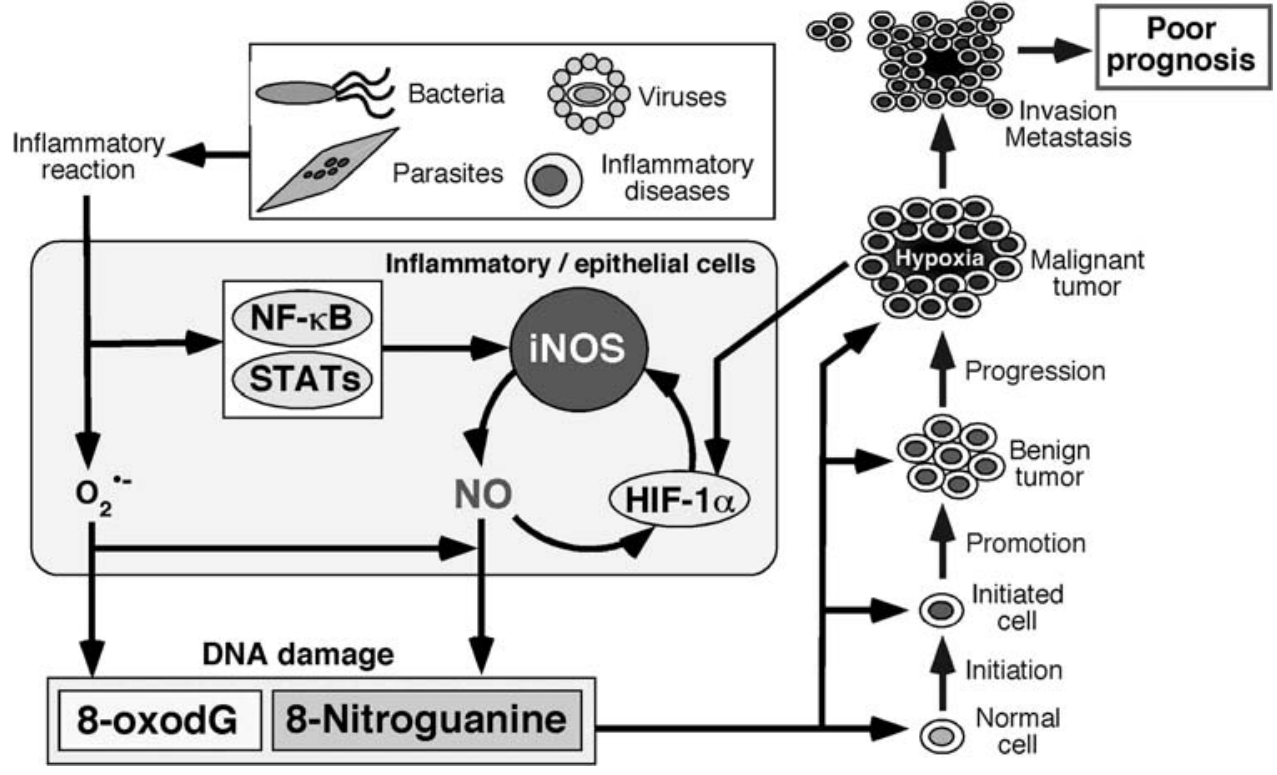

MFH patients [32]. iNOS, NF- $\kappa \mathrm{B}, \mathrm{COX}-2$, and hypoxiainducible factor (HIF)- $1 \alpha$ have been colocalized with 8-nitroguanine in MFH tissues [32, 33]. Tumor cells adapt to hypoxia by increasing the expression of HIF- $1 \alpha$, which mediates the transcription of various genes, including iNOS [84]. On the other hand, an increase in NO production through iNOS expression induces the accumulation and activation of HIF- $1 \alpha[85,86]$. Therefore, reciprocal activation between HIF- $1 \alpha$ and iNOS during tumor growth mediates persistent nitrative stress and resultant DNA damage, resulting in a poor prognosis of cancer patients. A recent study has demonstrated that $\mathrm{I} \kappa \mathrm{B}$ kinase (IKK)- $\beta$, which is involved in NF- $\kappa \mathrm{B}$ activation, is required for HIF$1 \alpha$ protein accumulation under hypoxia in cultured cells and animals [87], whereas NF- $\kappa \mathrm{B}$ is regulated under hypoxia in an HIF-1 $\alpha$-dependent manner [88]. Thus, reciprocal activation of HIF- $1 \alpha$ and NF- $\kappa$ B may be also involved in DNA damage and carcinogenesis.

In a study relevant to this concept, we demonstrated that in cholangiocarcinoma patients, 8-nitroguanine and 8-oxodG were formed in cancerous tissues to a much greater extent than in the adjacent non-cancerous tissues. Moreover, these DNA lesions in cancerous and adjacent tissues were associated with tumor invasion [29]. These results suggest that 8-nitroguanine participates in tumor progression and that it could be used as a biomarker to evaluate the prognosis of cancer patients.

\section{Conclusion and future perspectives}

Our group has investigated 8-nitroguanine formation in various clinical specimens and animal models in relation to inflammation-related carcinogenesis and found that 8-nitroguanine was formed at sites of carcinogenesis induced by chronic infection and various inflammatory conditions. We have also shown that 8-nitroguanine formation occurred in bronchial epithelial cells in the lung of asbestos-exposed mice (unpublished data). Experimental evidence has been provided for the mutagenic potential of 8-nitroguanine, which preferentially leads to $\mathrm{G} \rightarrow \mathrm{T}$ transversions $[15,19]$. Indeed, this type of mutation has been found to occur in vivo in the ras gene [89] and the $p 53$ tumor suppressor gene in lung and liver cancer [90, 91]. These findings imply that DNA damage mediated by ROS and RNS may participate in carcinogenesis via activation of protooncogenes and inactivation of tumor suppressor genes. Moreover, 8-nitroguanosine is a highly redox-active molecule that strongly stimulates $\mathrm{O}_{2}^{--}$generation [92]. 3-Nitrotyrosine, a biomarker of inflammation, is capable of inducing oxidative DNA damage via the redox reaction [93]. Therefore, such inflammation-derived nitrated molecules may serve as mutagens and participate in carcinogenesis via additional oxidative stress.

Based on the results of our studies, we have proposed a possible mechanism of inflammation-related carcinogenesis and tumor development via DNA damage, shown in Fig. 5. Various pathogenic agents, including bacteria, viruses, parasites, and other environmental factors, induce inflammatory responses and the production of ROS and RNS from inflammatory and epithelial cells. iNOS expression is regulated by transcription factors, including NF- $\kappa$ B, STAT, and HIF- $1 \alpha$, and NO can also activate these transcription factors. HIF- $1 \alpha$ is upregulated in a hypoxic environment during tumor growth and participates in tumor progression. Collectively, various molecular events 
converge to nitrative stress, and the resulting DNA damage contributes to the accumulation of genetic alterations in tissues throughout the carcinogenic process. In particular, 8-nitroguanine formation may participate in inflammationrelated carcinogenesis as a common mechanism and can be used as a potential biomarker to evaluate the cancer risk.

The establishment of the methods for quantitative analysis of 8-nitroguanine in biological or clinical specimens would be useful to evaluate the risk of inflammation-related carcinogenesis. 8-Nitroguanine formed in DNA is chemically unstable and is likely to be released from DNA. Thus, this characteristic may hamper its quantitative analysis. Recently, an attempt has been made to utilize free 8-nitroguanine in urine for quantitative analysis using a high-performance liquid chromatography-electrochemical detection method coupled with immunoaffinity purification [94]. 8-Nitroguanine has also been measured by liquid chromatography with mass spectrometry and glyoxal derivatization [95]. The establishment of a quantitative analysis of 8-nitroguanine in biological samples, such as blood and urine, would be useful for evaluation of the risk of inflammation-related carcinogenesis and would contribute to cancer prevention and the improved prognosis of cancer patients.

Acknowledgments The author is grateful to Professor Shosuke Kawanishi (Suzuka University of Medical Sciences), Professor Mariko Murata (Mie University Graduate School of Medicine), and all collaborators for their encouragement throughout this work. This work was supported by Grants-in-Aid for Scientific Research from the Ministry of Education, Culture, Sports, Science and Technology and the Ministry of Health, Labour and Welfare of Japan.

\section{References}

1. Balkwill F, Mantovani A. Inflammation and cancer: back to Virchow? Lancet. 2001;357:539-45.

2. Coussens LM, Werb Z. Inflammation and cancer. Nature. 2002;420:860-7.

3. Hussain SP, Harris CC. Inflammation and cancer: an ancient link with novel potentials. Int J Cancer. 2007;121:2373-80.

4. IARC. Chronic infections. In: Stewart BW, Kleihues P, editors. World Cancer Report. Lyon: IARC Press; 2003. p. 56-61.

5. Ohshima H, Tatemichi M, Sawa T. Chemical basis of inflammation-induced carcinogenesis. Arch Biochem Biophys. 2003; 417:3-11.

6. Hussain SP, Hofseth LJ, Harris CC. Radical causes of cancer. Nat Rev Cancer. 2003;3:276-85.

7. Kawanishi S, Hiraku Y. Oxidative and nitrative DNA damage as biomarker for carcinogenesis with special reference to inflammation. Antioxid Redox Signal. 2006;8:1047-58.

8. Kawanishi S, Hiraku Y, Pinlaor S, Ma N. Oxidative and nitrative DNA damage in animals and patients with inflammatory diseases in relation to inflammation-related carcinogenesis. Biol Chem. 2006;387:365-72.

9. Wiseman H, Halliwell B. Damage to DNA by reactive oxygen and nitrogen species: role in inflammatory disease and progression to cancer. Biochem J. 1996;313(Pt 1):17-29.
10. Kawanishi S, Hiraku Y, Oikawa S. Mechanism of guaninespecific DNA damage by oxidative stress and its role in carcinogenesis and aging. Mutat Res. 2001;488:65-76.

11. Kawanishi S, Hiraku Y, Murata M, Oikawa S. The role of metals in site-specific DNA damage with reference to carcinogenesis. Free Radic Biol Med. 2002;32:822-32.

12. Evans MD, Dizdaroglu M, Cooke MS. Oxidative DNA damage and disease: induction, repair and significance. Mutat Res. 2004;567:1-61.

13. Shibutani S, Takeshita M, Grollman AP. Insertion of specific bases during DNA synthesis past the oxidation-damaged base 8-oxodG. Nature. 1991;349:431-4.

14. Bruner SD, Norman DP, Verdine GL. Structural basis for recognition and repair of the endogenous mutagen 8-oxoguanine in DNA. Nature. 2000;403:859-66.

15. Yermilov V, Rubio J, Becchi M, Friesen MD, Pignatelli B, Ohshima H. Formation of 8-nitroguanine by the reaction of guanine with peroxynitrite in vitro. Carcinogenesis. 1995;16:2045-50.

16. Inoue S, Kawanishi S. Oxidative DNA damage induced by simultaneous generation of nitric oxide and superoxide. FEBS Lett. 1995;371:86-8.

17. Loeb LA, Preston BD. Mutagenesis by apurinic/apyrimidinic sites. Annu Rev Genet. 1986;20:201-30.

18. Wu X, Takenaka K, Sonoda E, Hochegger H, Kawanishi S, Kawamoto $\mathrm{T}$, et al. Critical roles for polymerase $\zeta$ in cellular tolerance to nitric oxide-induced DNA damage. Cancer Res. 2006;66:748-54.

19. Suzuki N, Yasui M, Geacintov NE, Shafirovich V, Shibutani S. Miscoding events during DNA synthesis past the nitrationdamaged base 8-nitroguanine. Biochemistry. 2005;44:9238-45.

20. Akaike T, Okamoto S, Sawa T, Yoshitake J, Tamura F, Ichimori $\mathrm{K}$, et al. 8-Nitroguanosine formation in viral pneumonia and its implication for pathogenesis. Proc Natl Acad Sci USA. 2003;100:685-90.

21. Pinlaor S, Hiraku Y, Ma N, Yongvanit P, Semba R, Oikawa S, et al. Mechanism of NO-mediated oxidative and nitrative DNA damage in hamsters infected with Opisthorchis viverrini: a model of inflammation-mediated carcinogenesis. Nitric Oxide. 2004;11:175-83.

22. Hiraku Y, Kawanishi S. Immunohistochemical analysis of 8-nitroguanine, a nitrative DNA lesion, in relation to inflammationassociated carcinogenesis. Methods Mol Biol. 2009;512:3-13.

23. Pinlaor S, Yongvanit P, Hiraku Y, Ma N, Semba R, Oikawa S, et al. 8-Nitroguanine formation in the liver of hamsters infected with Opisthorchis viverrini. Biochem Biophys Res Commun. 2003;309:567-71.

24. Pinlaor S, Ma N, Hiraku Y, Yongvanit P, Semba R, Oikawa S, et al. Repeated infection with Opisthorchis viverrini induces accumulation of 8-nitroguanine and 8-oxo-7, 8-dihydro-2'deoxyguanine in the bile duct of hamsters via inducible nitric oxide synthase. Carcinogenesis. 2004;25:1535-42.

25. Ma N, Adachi Y, Hiraku Y, Horiki N, Horiike S, Imoto I, et al. Accumulation of 8-nitroguanine in human gastric epithelium induced by Helicobacter pylori infection. Biochem Biophys Res Commun. 2004;319:506-10.

26. Horiike S, Kawanishi S, Kaito M, Ma N, Tanaka H, Fujita N, et al. Accumulation of 8-nitroguanine in the liver of patients with chronic hepatitis C. J Hepatol. 2005;43:403-10.

27. Hiraku Y, Tabata T, Ma N, Murata M, Ding X, Kawanishi S. Nitrative and oxidative DNA damage in cervical intraepithelial neoplasia associated with human papilloma virus infection. Cancer Sci. 2007;98:964-72.

28. Ma N, Kawanishi M, Hiraku Y, Murata M, Huang GW, Huang Y, et al. Reactive nitrogen species-dependent DNA damage in EBV-associated nasopharyngeal carcinoma: The relation to 
STAT3 activation and EGFR expression. Int $\mathrm{J}$ Cancer. 2008;122:2517-25.

29. Pinlaor S, Sripa B, Ma N, Hiraku Y, Yongvanit P, Wongkham S, et al. Nitrative and oxidative DNA damage in intrahepatic cholangiocarcinoma patients in relation to tumor invasion. World $\mathbf{J}$ Gastroenterol. 2005;11:4644-9.

30. Chaiyarit P, Ma N, Hiraku Y, Pinlaor S, Yongvanit P, Jintakanon $D$, et al. Nitrative and oxidative DNA damage in oral lichen planus in relation to human oral carcinogenesis. Cancer Sci. 2005;96:553-9.

31. Ma N, Tagawa T, Hiraku Y, Murata M, Ding X, Kawanishi S. 8Nitroguanine formation in oral leukoplakia, a premalignant lesion. Nitric Oxide. 2006;14:137-43.

32. Hoki Y, Hiraku Y, Ma N, Murata M, Matsumine A, Nagahama $\mathrm{M}$, et al. iNOS-dependent DNA damage in patients with malignant fibrous histiocytoma in relation to prognosis. Cancer Sci. 2007;98:163-8.

33. Hoki Y, Murata M, Hiraku Y, Ma N, Matsumine A, Uchida A, et al. 8-Nitroguanine as a potential biomarker for progression of malignant fibrous histiocytoma, a model of inflammation-related cancer. Oncol Rep. 2007;18:1165-9.

34. IARC. Infection with liver flukes (Opisthorchis viverrini, Opisthorchis felineus and Clonorchis sinensis ). In: IARC monographs on the evaluation of carcinogenic risks to humans. vol 61. Lyon: IARC Press; 1994. p. 121-75.

35. Haswell-Elkins MR, Mairiang E, Mairiang $P$, Chaiyakum J, Chamadol N, Loapaiboon V, et al. Cross-sectional study of Opisthorchis viverrini infection and cholangiocarcinoma in communities within a high-risk area in northeast Thailand. Int $\mathbf{J}$ Cancer. 1994;59:505-9.

36. Kaewkes S. Taxonomy and biology of liver flukes. Acta Trop. 2003;88:177-86.

37. Uttararvichen T, Buddhiswasdi V, Pairojkul C. Bile duct cancer and the liver fluke: pathology, presentation and surgical Management. Asian J Surg. 1996;19:267-70.

38. Pinlaor S, Hiraku Y, Yongvanit P, Tada-Oikawa S, Ma N, Pinlaor $\mathrm{P}$, et al. iNOS-dependent DNA damage via NF- $\kappa \mathrm{B}$ expression in hamsters infected with Opisthorchis viverrini and its suppression by the antihelminthic drug praziquantel. Int $\mathrm{J}$ Cancer. 2006;119:1067-72.

39. Sripa B, Kaewkes S. Localisation of parasite antigens and inflammatory responses in experimental opisthorchiasis. Int $\mathbf{J}$ Parasitol. 2000;30:735-40.

40. Pinlaor S, Tada-Oikawa S, Hiraku Y, Pinlaor P, Ma N, Sithithaworn $\mathrm{P}$, et al. Opisthorchis viverrini antigen induces the expression of Toll-like receptor 2 in macrophage RAW cell line. Int J Parasitol. 2005;35:591-6.

41. Williams CS, Tsujii M, Reese J, Dey SK, DuBois RN. Host cyclooxygenase- 2 modulates carcinoma growth. J Clin Invest. 2000;105:1589-94.

42. Warner TD, Mitchell JA. Cyclooxygenases: new forms, new inhibitors, and lessons from the clinic. FASEB J. 2004;18:790-804.

43. Kundu JK, Surh YJ. Inflammation: gearing the journey to cancer. Mutat Res. 2008;659:15-30.

44. Karin M, Greten FR. NF- $\kappa$ B: linking inflammation and immunity to cancer development and progression. Nat Rev Immunol. 2005;5:749-59.

45. Pikarsky E, Porat RM, Stein I, Abramovitch R, Amit S, Kasem S, et al. NF- $\kappa \mathrm{B}$ functions as a tumour promoter in inflammationassociated cancer. Nature. 2004;431:461-6.

46. Karin M. Nuclear factor $-\kappa \mathrm{B}$ in cancer development and progression. Nature. 2006;441:431-6.

47. O'Neill LA, Greene C. Signal transduction pathways activated by the IL-1 receptor family: ancient signaling machinery in mammals, insects, and plants. J Leukoc Biol. 1998;63:650-7.
48. Kawai T, Akira S. Signaling to NF- $\kappa$ B by Toll-like receptors. Trends Mol Med. 2007;13:460-9.

49. Rakoff-Nahoum S, Medzhitov R. Toll-like receptors and cancer. Nat Rev Cancer. 2009;9:57-63.

50. Kim S, Takahashi H, Lin WW, Descargues P, Grivennikov S, Kim Y, et al. Carcinoma-produced factors activate myeloid cells through TLR2 to stimulate metastasis. Nature. 2009; 457:102-6.

51. IARC. Cancers of the female reproductive tract. In: Stewart BW, Kleihues P, editors. World Cancer Report. Lyon: IARC Press; 2003. p. $215-22$.

52. Tindle RW. Immune evasion in human papillomavirus-associated cervical cancer. Nat Rev Cancer. 2002;2:59-65.

53. Munoz N, Bosch FX, de Sanjose S, Herrero R, Castellsague X, Shah KV, et al. Epidemiologic classification of human papillomavirus types associated with cervical cancer. N Engl J Med. 2003;348:518-27.

54. Chen YC, Hunter DJ. Molecular epidemiology of cancer. CA Cancer J Clin. 2005;55:45-54.

55. IARC. Human papillomaviruses. In: IARC monographs on the evaluation of carcinogenic risks to humans. vol 64. Lyon: IARC Press; 1995. p. 35-378.

56. IARC. Human papillomaviruses. In: IARC monographs on the evaluation of carcinogenic risks to humans. vol 90. Lyon: IARC Press; 2007. p. 45-636.

57. Castle PE, Giuliano AR. Chapter 4: genital tract infections, cervical inflammation, and antioxidant nutrients-assessing their roles as human papillomavirus cofactors. J Natl Cancer Inst Monogr. 2003;31:29-34.

58. von Knebel Doeberitz M. New markers for cervical dysplasia to visualise the genomic chaos created by aberrant oncogenic papillomavirus infections. Eur J Cancer. 2002;38:2229-42.

59. Duensing S, Munger K. Mechanisms of genomic instability in human cancer: insights from studies with human papillomavirus oncoproteins. Int J Cancer. 2004;109:157-62.

60. DiPaolo JA, Woodworth CD, Popescu NC, Notario V, Doniger J. Induction of human cervical squamous cell carcinoma by sequential transfection with human papillomavirus 16 DNA and viral Harvey ras. Oncogene. 1989;4:395-9.

61. Du MQ, Carmichael PL, Phillips DH. Induction of activating mutations in the human c-Ha-ras-1 proto-oncogene by oxygen free radicals. Mol Carcinog. 1994;11:170-5.

62. Castle PE, Hillier SL, Rabe LK, Hildesheim A, Herrero R, Bratti $\mathrm{MC}$, et al. An association of cervical inflammation with highgrade cervical neoplasia in women infected with oncogenic human papillomavirus (HPV). Cancer Epidemiol Biomarkers Prev. 2001;10:1021-7.

63. Smith JS, Herrero R, Bosetti C, Munoz N, Bosch FX, Eluf-Neto $\mathrm{J}$, et al. Herpes simplex virus-2 as a human papillomavirus cofactor in the etiology of invasive cervical cancer. J Natl Cancer Inst. 2002;94:1604-13.

64. Kulkarni S, Rader JS, Zhang F, Liapis H, Koki AT, Masferrer JL, et al. Cyclooxygenase- 2 is overexpressed in human cervical cancer. Clin Cancer Res. 2001;7:429-34.

65. Kim GE, Kim YB, Cho NH, Chung HC, Pyo HR, Lee JD, et al. Synchronous coexpression of epidermal growth factor receptor and cyclooxygenase- 2 in carcinomas of the uterine cervix: a potential predictor of poor survival. Clin Cancer Res. 2004;10:1366-74.

66. Sano T, Oyama T, Kashiwabara K, Fukuda T, Nakajima T. Expression status of p16 protein is associated with human papillomavirus oncogenic potential in cervical and genital lesions. Am J Pathol. 1998;153:1741-8.

67. Klaes R, Friedrich T, Spitkovsky D, Ridder R, Rudy W, Petry U, et al. Overexpression of p16(INK4A) as a specific marker for 
dysplastic and neoplastic epithelial cells of the cervix uteri. Int $\mathbf{J}$ Cancer. 2001;92:276-84.

68. Wang JL, Zheng BY, Li XD, Angstrom T, Lindstrom MS, Wallin KL. Predictive significance of the alterations of p16INK4A, p14ARF, p53, and proliferating cell nuclear antigen expression in the progression of cervical cancer. Clin Cancer Res. 2004;10:2407-14.

69. Khleif SN, DeGregori J, Yee CL, Otterson GA, Kaye FJ, Nevins JR, et al. Inhibition of cyclin D-CDK4/CDK6 activity is associated with an E2F-mediated induction of cyclin kinase inhibitor activity. Proc Natl Acad Sci USA. 1996;93:4350-4.

70. IARC. Epstein-Barr virus. In: IARC monographs on the evaluation of carcinogenic risks to humans. vol 70. Lyon: IARC Press; 1997. p. 47-373.

71. Jeannel D, Bouvier G, Huber A. Nasopharyngeal carcinoma: an epidemiological approach to carcinogenesis. Cancer Surv. 1999; 33:125-55.

72. McDermott AL, Dutt SN, Watkinson JC. The aetiology of nasopharyngeal carcinoma. Clin Otolaryngol Allied Sci. 2001;26:82-92.

73. Tsai ST, Jin YT, Mann RB, Ambinder RF. Epstein-Barr virus detection in nasopharyngeal tissues of patients with suspected nasopharyngeal carcinoma. Cancer. 1998;82:1449-53.

74. Miller WE, Cheshire JL, Baldwin AS Jr, Raab-Traub N. The NPC derived C15 LMP1 protein confers enhanced activation of NF- $\kappa \mathrm{B}$ and induction of the EGFR in epithelial cells. Oncogene. 1998;16:1869-77.

75. Tao Y, Song X, Deng X, Xie D, Lee LM, Liu Y, et al. Nuclear accumulation of epidermal growth factor receptor and acceleration of G1/S stage by Epstein-Barr-encoded oncoprotein latent membrane protein 1. Exp Cell Res. 2005;303:240-51.

76. Lo HW, Hsu SC, Ali-Seyed M, Gunduz M, Xia W, Wei Y, et al. Nuclear interaction of EGFR and STAT3 in the activation of the iNOS/NO pathway. Cancer Cell. 2005;7:575-89.

77. Lo KW, To KF, Huang DP. Focus on nasopharyngeal carcinoma. Cancer Cell. 2004;5:423-8.

78. IARC. Salted fish. In: IARC monographs on the evaluation of carcinogenic risks to humans. vol 56. Lyon: IARC Press; 1993. p. 41-82.

79. Hildesheim A, West S, DeVeyra E, De Guzman MF, Jurado A, Jones C, et al. Herbal medicine use, Epstein-Barr virus, and risk of nasopharyngeal carcinoma. Cancer Res. 1992;52:3048-51.

80. Takeda N, Ohigashi H, Hirai N, Koshimizu K, Suzuki M, Tatematsu A, et al. Mass spectrometric identification of a phorbol diester 12-O-hexadecanoylphorbol-13-acetate, an Epstein-Barr virus-activating substance, in the soil collected from under Sapium sebiferum. Cancer Lett. 1991;59:153-8.

81. Weiss SW, Goldbum JR. Enzinger and Weiss's Soft tissue tumors. 4th ed. St. Louis: Mosby; 2002.

82. Melhem MF, Meisler AI, Saito R, Finley GG, Hockman HR, Koski RA. Cytokines in inflammatory malignant fibrous histiocytoma presenting with leukemoid reaction. Blood. 1993;82:2038-44.

83. Richter KK, Parham DM, Scheele J, Hinze R, Rath FW. Presarcomatous lesions of experimentally induced sarcomas in rats: morphologic, histochemical, and immunohistochemical features. In Vivo. 1999;13:349-55.

84. Harris AL. Hypoxia- a key regulatory factor in tumour growth. Nat Rev Cancer. 2002;2:38-47.

85. Mateo J, Garcia-Lecea M, Cadenas S, Hernandez C, Moncada S. Regulation of hypoxia-inducible factor- $1 \alpha$ by nitric oxide through mitochondria-dependent and -independent pathways. Biochem J. 2003;376:537-44.

86. Thomas DD, Espey MG, Ridnour LA, Hofseth LJ, Mancardi D, Harris CC, et al. Hypoxic inducible factor $1 \alpha$, extracellular signal-regulated kinase, and p53 are regulated by distinct threshold concentrations of nitric oxide. Proc Natl Acad Sci USA. 2004;101:8894-9.

87. Rius J, Guma M, Schachtrup C, Akassoglou K, Zinkernagel AS, Nizet $\mathrm{V}$, et al. NF- $\kappa \mathrm{B}$ links innate immunity to the hypoxic response through transcriptional regulation of HIF-1 $\alpha$. Nature. 2008;453:807-11.

88. Walmsley SR, Print C, Farahi N, Peyssonnaux C, Johnson RS, Cramer T, et al. Hypoxia-induced neutrophil survival is mediated by HIF- $1 \alpha$-dependent NF- $\kappa$ B activity. J Exp Med. 2005;201:10515.

89. Bos JL. The ras gene family and human carcinogenesis. Mutat Res. 1988; 195:255-71.

90. Takahashi T, Nau MM, Chiba I, Birrer MJ, Rosenberg RK, Vinocour M, et al. p53: a frequent target for genetic abnormalities in lung cancer. Science. 1989;246:491-4.

91. Hsu IC, Metcalf RA, Sun T, Welsh JA, Wang NJ, Harris CC. Mutational hotspot in the $p 53$ gene in human hepatocellular carcinomas. Nature. 1991;350:427-8.

92. Sawa T, Akaike T, Ichimori K, Akuta T, Kaneko K, Nakayama $\mathrm{H}$, et al. Superoxide generation mediated by 8-nitroguanosine, a highly redox-active nucleic acid derivative. Biochem Biophys Res Commun. 2003;311:300-6.

93. Murata M, Kawanishi S. Oxidative DNA damage induced by nitrotyrosine, a biomarker of inflammation. Biochem Biophys Res Commun. 2004;316:123-8.

94. Sawa T, Tatemichi M, Akaike T, Barbin A, Ohshima H. Analysis of urinary 8-nitroguanine, a marker of nitrative nucleic acid damage, by high-performance liquid chromatography-electrochemical detection coupled with immunoaffinity purification: Association with cigarette smoking. Free Radic Biol Med. 2006;40:711-20.

95. Ishii Y, Ogara A, Okamura T, Umemura T, Nishikawa A, Iwasaki $\mathrm{Y}$, et al. Development of quantitative analysis of 8-nitroguanine concomitant with 8-hydroxydeoxyguanosine formation by liquid chromatography with mass spectrometry and glyoxal derivatization. J Pharm Biomed Anal. 2007;43:1737-43. 